\title{
Calcium Lactate addition in Bioconcrete: Effect on Compressive strength and Water penetration
}

\author{
J.M Irwan ${ }^{1, *}$, L.H Anneza ${ }^{1}$, N. Othman ${ }^{2}$, A. Faisal Alshalif ${ }^{1}$, M.M. Zamer ${ }^{1}$, and $T$. \\ Teddy ${ }^{1}$ \\ ${ }^{1}$ Jamilus Research Centre for Sustainable Construction (JRC), Faculty of Civil and Environmental \\ Engineering,University Tun Hussein Onn, Malaysia. \\ ${ }^{2}$ Micropollutant Research Centre (MPRC),Faculty of Civil and Environmental \\ Engineering,University Tun Hussein Onn, Malaysia.
}

\begin{abstract}
This paper presents compressive strength and water penetration of bioconcrete with addition of calcium lactate. Bioconcrete has higher engineering concrete properties and durability compared to normal concrete but the natural production of calcium carbonate is limited to the calcium content in cement. Therefore, additional calcium is added as an additional calcium source to study the influence towards compressive strength and water penetration. The bacteria used in this research are Enterococcus faecalis and Bacillus sp. Calcium lactate was added into concrete mix in concentrations of $0.001 \mathrm{~mol} / 1,0.005 \mathrm{~mol} / 1$ and $0.01 \mathrm{~mol} / 1$ of liquid used. The concentration of bacteria added into the mix is by partial replacement of water used in casting, which are 3\% for Enterococcus faecalisand $5 \%$ for Bacillus sp. Both compressive strength and water penetration test used cubes of $150 \mathrm{~mm} \times 150 \mathrm{~mm} \times 150 \mathrm{~mm}$. The cubes were tested after 28 days. The result of compressive strength for control is 36 MPa while partial replacement of bacteria yields $38.2 \mathrm{MPa}$ for $3 \%$ Enterococcus faecalisand $37.0 \mathrm{MPa}$ for $5 \%$ Bacillus sp. Calcium lactate with $0.005 \mathrm{~mol} / \mathrm{L}$ has the best performance with $42.8 \mathrm{MPa}$ for Enterococcus faecalis and $39.6 \mathrm{MPa}$ for Bacillus $s p$. Whereas for water penetration, the best concentration of calcium lactate which yielded the lowest water penetration is $0.01 \mathrm{~mol} / 1$ for both Enterococcus faecalis and Bacillus $s p$ which are $8.7 \mathrm{~cm}$ and $8 \mathrm{~cm}$ respectively. The addition of calcium lactate into bioconcrete is quite promising for improvement of concrete properties and durability.
\end{abstract}

\section{Introduction}

Over the years, many researchers had studied the addition of waste material into concrete [1-3]. Another green alternative for improving concrete that is currently explored by many researchers is bioconcrete. Bioconcrete is a combination of biological micro-organisms and concrete. The use of micro-organisms in concrete is due to the ability to produce calcium carbonate [4]. Different bacteria from various sources are used by researchers studying bioconcrete. Bacteria that was known as Shewanella was isolated from the mud of the hot springs in West Bengal, India. This bacteria is used to improve concrete properties [5]. The

\footnotetext{
* Corresponding author: irwan@uthm.edu.my
} 
use of Bacillus pasteurii and Pseudomonas aeruginosa which are endospore-forming soil micro-organism are used in Ramachandran [6]. A significant decrease in water uptake resulted by the addition of bacteria in concrete. The surface deposition of calcium carbonate crystals decreased the water absorption by $85 \%$, depending on the porosity of specimens [7]. The bacteria used in this study is Enterococcus faecalis and Bacillus sp, both of this bacteria are isolated and enriched to suit the concrete environment. The isolation, enrichment and the amount of bacteria added as a partial replacement is based on a previously conducted study by Irwan $[8,9]$. Adding calcium source in the concrete helps in increasing the amount of precipitated calcium carbonate and therefore increases strength and improve durability. The amount of precipitated calcium carbonate depends on in the type of calcium source added [10].

\section{Experimental Investigation}

\subsection{Material}

The total amount of materials that was used in this research is shown in Table 1. Ordinary Portland cement, coarse and fine aggregates were used in the concrete mix. The aggregates were prepared according to BS 882.1992. Both Enterococcus faecalis (Ent.f) and Bacillus $s p(B . s p)$ were added as partial replacement of water, $3 \%$ and $5 \%$ respectively. The concentration of calcium lactate added is based on $0.001 \mathrm{~mol} / 1,0.005 \mathrm{~mol} / 1$ and $0.01 \mathrm{~mol} / 1$ of the amount of water. The calculation for calcium lactate is based on the chemical formula $\left(\mathrm{C}_{6} \mathrm{H}_{10} \mathrm{CaO}_{6}\right)$ with molar mass $(218 \mathrm{~g} / \mathrm{mol})$ of calcium lactate. Therefore, concentration are used as $0.22 \mathrm{~g} / \mathrm{L}, 1.09 \mathrm{~g} / \mathrm{L}$ and $2.18 \mathrm{~g} / \mathrm{L}$ for $0.001 \mathrm{~mol} / 1,0.005 \mathrm{~mol} / 1$ and $0.01 \mathrm{~mol} / 1$ respectively.

Table 1. Amount of materials used for fabrication.

\begin{tabular}{|c|c|c|c|c|c|c|}
\hline Batch & $\begin{array}{c}\text { Cement } \\
\text { (kg) }\end{array}$ & $\begin{array}{c}\text { Fine } \\
\text { aggregate } \\
\text { (kg) }\end{array}$ & $\begin{array}{c}\text { Coarse } \\
\text { aggregate } \\
(\mathrm{kg})\end{array}$ & $\begin{array}{c}\text { Water } \\
\text { (kg) }\end{array}$ & $\begin{array}{l}\text { Bacteria } \\
\text { (kg) }\end{array}$ & $\begin{array}{c}\text { Calcium } \\
\text { lactate } \\
\text { (g) }\end{array}$ \\
\hline Control & 7.9 & 13.9 & 22.6 & 4.3 & - & - \\
\hline $\begin{array}{c}\text { 3\% Enterococcus } \\
\text { faecalis (Ent.f) }\end{array}$ & 7.9 & 13.9 & 22.6 & 4.2 & 0.13 & - \\
\hline $\begin{array}{l}3 \% \text { Ent. } f+0.001 \\
\mathrm{~mol} / \mathrm{l}\end{array}$ & 7.9 & 13.9 & 22.6 & 4.2 & 0.13 & 1 \\
\hline $\begin{array}{c}3 \% \text { Ent. } f+0.005 \\
\mathrm{~mol} / \mathrm{l}\end{array}$ & 7.9 & 13.9 & 22.6 & 4.2 & 0.13 & 4.7 \\
\hline $\begin{array}{c}3 \% \text { Ent.f }+0.01 \\
\mathrm{~mol} / \mathrm{l}\end{array}$ & 7.9 & 13.9 & 22.6 & 4.2 & 0.13 & 9.4 \\
\hline $\begin{array}{c}5 \% \text { Bacillus } s p \\
(\text { B.sp })\end{array}$ & 7.9 & 13.9 & 22.6 & 4.1 & 0.23 & - \\
\hline $\begin{array}{c}5 \% \text { B.sp }+0.001 \\
\mathrm{~mol} / \mathrm{l}\end{array}$ & 7.9 & 13.9 & 22.6 & 4.1 & 0.23 & 1 \\
\hline $\begin{array}{c}5 \% \text { B.sp+ } 0.005 \\
\mathrm{~mol} / 1\end{array}$ & 7.9 & 13.9 & 22.6 & 4.1 & 0.23 & 4.7 \\
\hline $\begin{array}{c}5 \% \text { B.sp+ } 0.01 \\
\mathrm{~mol} / 1\end{array}$ & 7.9 & 13.9 & 22.6 & 4.1 & 0.23 & 9.4 \\
\hline
\end{tabular}




\subsection{Preparation of bacteria and calcium lactate}

Both bacteria are prepared with the same method. Which is taking a colony of bacteria, adding it into sterilize nutrient broth and shaken for ten days. The number of days for optimum growth was determined by plotting bacteria growth curve using daily turbidity data. The bacteria are added into concrete mix as partial replacement of water.Calcium lactate is prepared by dissolving in water before adding into the mix.

\subsection{Fabrication of concrete and testing}

Fabrication of concrete is done according to BS 1881-125:2013. After the mix is complete, the bioconcrete is poured into plastic moulds of $150 \mathrm{~mm} \times 150 \mathrm{~mm} \times 150 \mathrm{~mm}$ then left to hardened for 24 hours. After 24 hours, the concrete is removed and left for dry curing. Compressive strength test and water penetration test are conducted after 28 days of maturity. The testing is done using three samples to get the average results. The average results of the test are presented.

\section{Results and discussion}

\subsection{Compressive strength}

The compressive strength had considerable improvement with concrete specimens containing bacteria and calcium lactate shown at Figure 1. The highest increment of compressive strength for both bacteria is with calcium lactate of $0.005 \mathrm{~mol} / 1$ concentration. The increment of concrete specimen strength with Ent.f and Ent.f with calcium lactate of $0.001 \mathrm{~mol} / 1,0.005 \mathrm{~mol} / 1$ and $0.01 \mathrm{~mol} / \mathrm{l}$ concentration compared to control are $6.11 \%$, $6.9 \%, 18.9 \%$ and $8.3 \%$ respectively. Whereas, the increment of strength for concrete specimens containing B.sp and B.sp with calcium lactate of $0.001 \mathrm{~mol} / \mathrm{l}, 0.005 \mathrm{~mol} / \mathrm{l}$ and $0.01 \mathrm{~mol} / \mathrm{l}$ concentrations compared to control are $2.7 \%, 6.9 \%, 10 \%$ and $5 \%$ respectively.

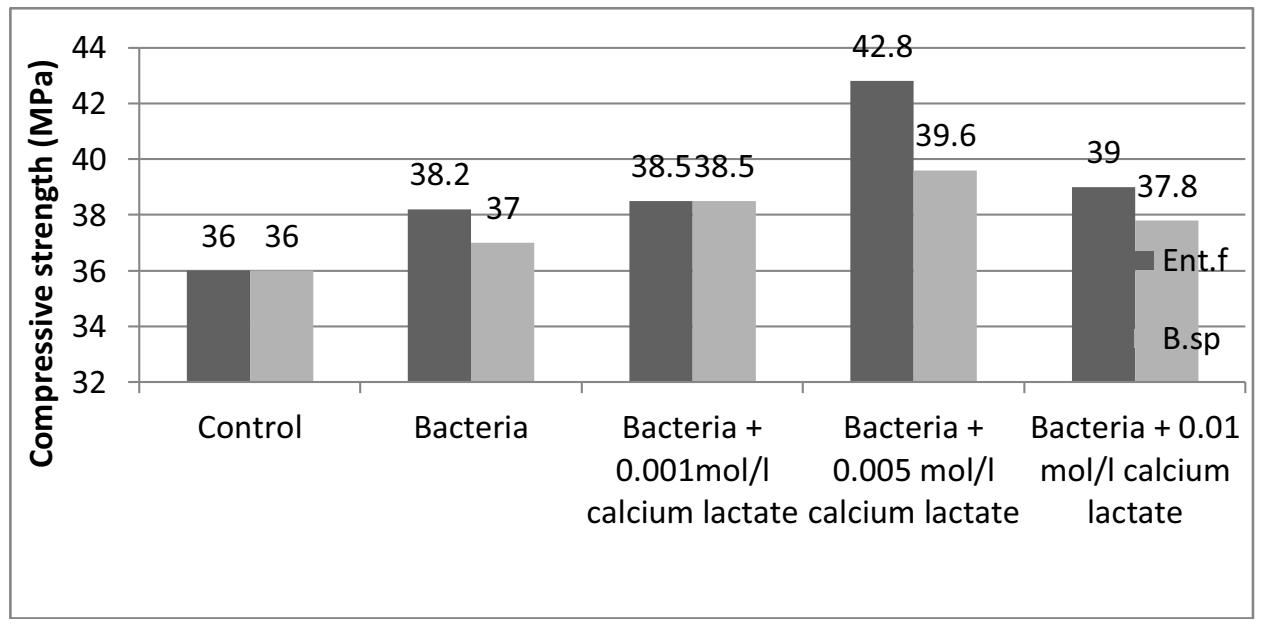

Fig. 1. Comparison Enterococcus faecalis and Bacillus sp with various concentration of calcium lactate. 
Irwan et al., has stated that materials added into concrete which does not participate in hydration process with the binder could attribute to decrease in compressive strength. Bacteria added into concrete does not directly involved in the hydration process itself but used the by-product of the reaction to produce calcium carbonate. The slight reduction of compressive strength with higher concentration of calcium lactate shows that over production of calcium carbonate would affect the compressive strength. Similar result is reported by Faiz and Steve [11], which stated that minimal amount of calcium carbonate was found most effective in increment of strength. Researchers have studied that certain concentration of bacteria increases compressive strength compared to control [4-7]. However, the concentration of bacteria depends on the bacteria itself. As every bacteria used are of different origins. Thus, may have different reactions. In Xu et al. [10] and AboEl-Enein [12] studies, calcium source were added into bioconcrete. After which compressive strength were tested and compared. It was found that different calcium source precipitates different amount of calcium carbonate. Different calcium source influence the rate of bacteria precipitation and amount.

The precipitation of calcium carbonate that fills the pore within the concrete matrix is the factor for increment of compressive strength. Addition of Ent.f in concrete has considerable impact on the compressive strength compared to B.sp. The obvious difference for both bacteria is with $0.005 \mathrm{~mol} / 1$ concentration of calcium lactate. Ent. $f$ has shown a tremendous increase of compressive strength compared to B.sp. This is due to Ent.f reaction to the addition of calcium source. The addition of calcium source allows the bacteria to increase precipitation which benefited the concrete. Calcium lactate with concentration of $0.01 \mathrm{~mol} / 1$ has caused an over production of calcium carbonate which cause the strength to reduce slightly. This is similar for both bacteria. The increment of strength with addition of bacteria are due to deposition of calcite facilitated by calcium nutrient $[10,14]$.

\subsection{Water penetration}

Bioconcrete specimens with different concentration of calcium lactate shows promising results, as seen in Figure 2. The lowest water penetration is with $0.01 \mathrm{~mol} / 1$ of calcium lactate for both bacteria. Concrete specimens with Ent.f and Ent.f with $0.001 \mathrm{~mol} / 1,0.005$ $\mathrm{mol} / 1$ and $0.01 \mathrm{~mol} / 1$ has decrease water penetration by $22 \%, 20 \%, 22.9 \%$ and $26.3 \%$ respectively compared to control. Whereas, concrete samples with B.sp and B.sp with 0.001 $\mathrm{mol} / \mathrm{l}, 0.005 \mathrm{~mol} / \mathrm{l}$ and $0.01 \mathrm{~mol} / \mathrm{l}$ decreased water uptake by $20.3 \%, 25 \%, 26.3 \%$ and $32.2 \%$ respectively compared to control.

The presence of bacteria reduces the water penetration of concrete by filling the pores with deposited calcium carbonate $[4,7,16]$. The addition of calcium source acts as a catalyst to further deposit calcium carbonate.

The increment of precipitation of calcium carbonate by calcium source in concrete containing bacteria plugs pores within the concrete matrix. This blocks the pathway for water to enter concrete which reduces the water penetration of concrete. With the addition of calcium lactate, the decrement of water penetration for B.sp is better than Ent.f. This is due to the reaction between the bacteria and calcium lactate within the concrete pores. The calcium lactate crystallizes within the pores which caused the pores to block up thus reduces the water penetration. Previous study has reported that calcite deposition in pores caused reduction in water uptake [4,7]. Xu and Yao [10] had reported that additional calcium source in bioconcrete reduced the water penetration and increased the concrete durability. 


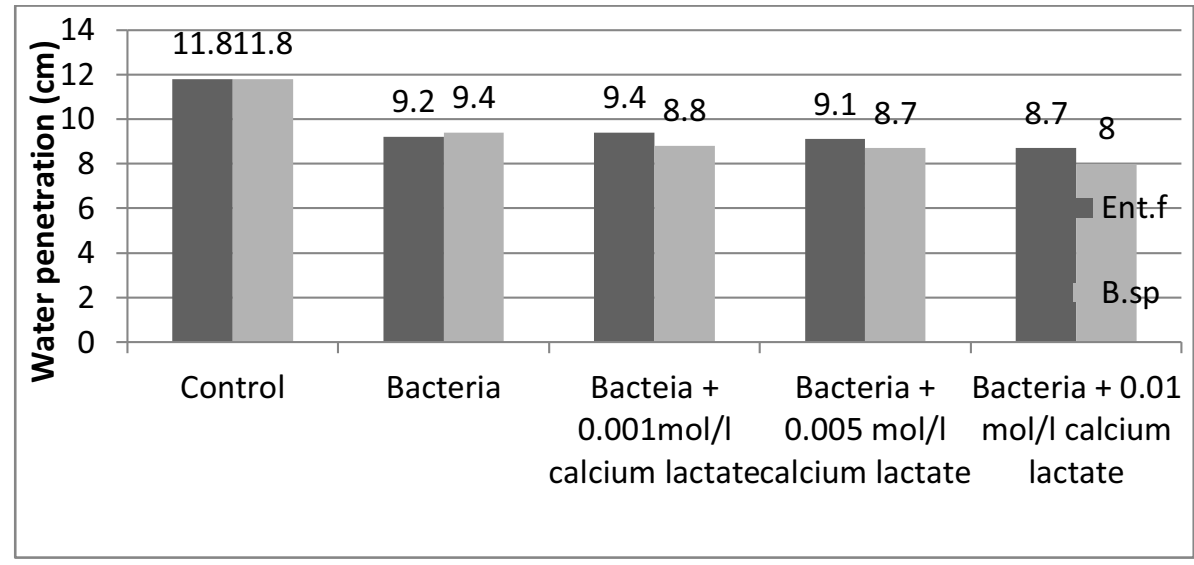

Fig. 2. Comparison Enterococcus faecalis and Bacillus $s p$ with various concentration of calcium lactate.

\section{Conclusion}

The results obtained in this research showed that concrete added with calcium lactate and bacteria has its advantages in improving concrete strength and durability. In terms of compressive strength, the optimum percentage of calcium lactate that is added is $0.005 \mathrm{~mol} / 1$ for both bacteria. While, water penetration shows that $0.01 \mathrm{~mol} / 1$ of calcium lactate is optimum for both bacteria.

This research was supported by UniversitiTun Hussein Onn Malaysia (UTHM) and The Ministry of Higher Education Malaysia through Fundamental Research Grant Scheme (FGRS), Vot 1211.

\section{References}

1. S.K. Faisal, J.M. Irwan, N. Othman, M.H. Wan Ibrahim, Flexural Toughness of RingShaped Waste Bottle Fiber Concrete (EDP Sciences, 2016)

2. S.A. Radziah, W.W.Z.A. Raziman, S.Shahiron, Physical and Mechanical Properties of Compressed Earth Brick (CEB) Containing Sugarcane Bagasse Ash (EDP Sciences, 2016)

3. J. Norwati, A.H. Farhan, M.W.I. Haziman, P.J. Ramadhansyah, M.A. Fadzil, Z.A. Norul Ernida, D. Nurol Huda, Fresh Properties and Flexural Strength of SelfCompacting Concrete Integrating Coal Bottom Ash (MATEC Web of Conference, IConCEES, 01010, 47 2016)

4. N. Chahal, R. Siddique, Constr. Build. Mater., 49, 161 (2013)

5. P. Ghosh, S. Mandal, Indian Journal Of Experimental Biology, 44(4), 336 (2006)

6. S.K. Ramachandran, V. Ramakrishnan, S.S. Bang, ACI Material Jurnal, 98(1), 3 (2001)

7. W.D. Muynck, K. Cox, N.D. Belie, W. Verstraete, Constr. Build. Mater., 22(5), 875 (2008)

8. J.M. Irwan, A. Faisal Alshalif, N. Othman, R.M Asyraf, Isolation of Ureolytic and Sulphate reduction bacteria: Acclimitize to concrete environment (Interntional conference on civil, Biological and Environmental Engineering (CBEE), Istanbul, Turkey 2014) 
9. J.M. Irwan, A. Faisal Alshalif, N. Othman, L.H. Anneza, Effect of Ureolytic Bacteria on Compressive strength and Water Permeability on Bio-concrete (International Conference on Civil, Architectural, Structural and Construction Engineering 2015).

10. J. Xu, W. Yao, Cement Concrete Res. 64, 1 (2014)

11. U.A. Faiz, Shaikh, W.M.S. Steve, Constr. Build. Mater., 70, 309 (2014)

12. S.A. Abo-El-Enein, A.H. Ali, Fatma, N. Talkhan, H.A. Abdel-Gawwad, Housing and building national research center journal, 9(1), 36 (2013) 